Check for updates

Cite this: RSC Adv., 2019, 9, 21616

\title{
Chemical constituents from the stems of Machilus philippinensis Merr. and the neuroprotective activity of cinnamophilin $\uparrow$
}

\author{
Shih-Huang Tai,,$^{\mathrm{a}}$ Ping-Chung Kuo, (D) $\ddagger^{\mathrm{b}}$ Sio Hong Lam, ${ }^{\mathrm{b}}$ Shiow-Chyn Huang, ${ }^{\mathrm{c}}$ \\ Yi-Zhuan Kuo, ${ }^{d}$ Hsin-Yi Hung, ${ }^{b}$ Meei-Jen Liou, ${ }^{e}$ Po-Chuen Shieh, ${ }^{f}$ E.-Jian Lee ${ }^{\star a}$ \\ and Tian-Shung Wu DD $^{* b f}$
}

\begin{abstract}
The Machilus genus (Lauraceae) had been extensively utilized in folk medicine due to its broad range of bioactivities. In the present study, a series of chromatographic separations of the methanol extract of stems of $M$. philippinensis led to the identification of thirty eight compounds totally. Among these, biscinnamophilin (1), machilupins A-C (2-4), machilutone A (5), and machilusoxide A (6) were new compounds reported for the first time. In addition, 5 was characterized with a unprecedented carbon skeleton. Other known compounds, including the major compounds cinnamophilin (7) and mesodihydroguaiaretic acid (8), are identified by comparison of their physical and spectroscopic data with reported values. One of the reported compounds, cinnamophilin A (10), should be revised as dehydroguaiaretic acid (9) after careful comparison of all the ${ }^{1} \mathrm{H}$ and ${ }^{13} \mathrm{C} N M R$ data. Moreover, the neuroprotective activity of cinnamophilin (7) was examined in a primary cortical neuron culture and the results indicated that 7 was effective against glutamate induced excitotoxicity.
\end{abstract}

Received 10th May 2019

Accepted 5th June 2019

DOI: $10.1039 / c 9 r a 03514 a$

rsc.li/rsc-advances

stress, but also improves behavioral outcome, as assessed at $24 \mathrm{~h}$ post-stroke. ${ }^{7}$ CINN protects against ischemic brain damage with a therapeutic window up to $6 \mathrm{~h}$ in vivo and in vitro, which may be attributed to its direct antioxidant and antiinflammatory effects. ${ }^{8,9}$ M. philippinensis had been utilized in folk medicine due to its broad range of bioactivities, including cytotoxic, ${ }^{10-13}$ antioxidant, ${ }^{14,15}$ antiinflammatory, ${ }^{8,16}$ antiplatelet aggregatory, ${ }^{17,18}$ and neuro-protective effects. ${ }^{7-9,19,20}$ In our continuing program aimed to screen for natural neuroprotective lead compounds from Formosan Lauraceous plants, exploring the complete chemical composition of M. philippinensis and searching for possible candidates for the treatment of stroke should be performed according to our previous experimental results. $^{7-9}$ In the present study, six new compounds 1-6 were characterized through spectroscopic and spectrometric analyses and the structural elucidations are discussed below.

${ }^{a}$ Department of Surgery, National Cheng Kung University Hospital, College of Medicine, National Cheng Kung University, Tainan 701, Taiwan

${ }^{b}$ School of Pharmacy, College of Medicine, National Cheng Kung University, Tainan 701, Taiwan.E-mail: tswu@mail.ncku.edu.tw

'Department of Pharmacy, Chia-Nan University of Pharmacy and Science, Tainan 717, Taiwan

${ }^{d}$ Department of Chemistry, National Cheng Kung University, Tainan 701, Taiwan ${ }^{\circ}$ Department of Applied Chemistry, Providence University, Taichung 433, Taiwan ${ }^{f}$ Department of Pharmacy, College of Pharmacy and Health Care, Tajen University, Pingtung 907, Taiwan

$\dagger$ Electronic supplementary information (ESI) available: Spectral data of compounds 1-6. See DOI: 10.1039/c9ra03514a

\$ S. H. Tai and P. C. Kuo contributed equally to this work.

\section{Results and discussion}

The powdered stems of $M$. philippinensis were reflux with methanol, and combined extracts were concentrated to produce the methanol extract. Processed with liquid-liquid partition and continuous conventional chromatographic techniques combination, totally thirty-eight compounds were characterized and among them compounds 1-6 were new (Fig. 1). Other known compounds were identified by comparison of their experimental data with those in the literature, including seven 
<smiles>COc1ccc(C(=O)[C@H](C)[C@@H](C)[C@@H](C)c2cc(OC)c(O)c(C(C)(C)C)c2)cc1OC</smiles>

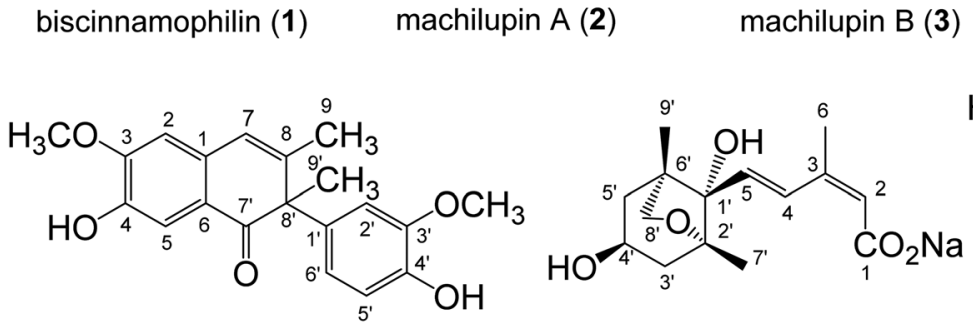

machilutone $A(5)$ machilusoxide $A(6)$<smiles>COc1cc(C[C@@H](C)[C@H](C)C(=O)c2ccc(O)c(OC)c2)ccc1O</smiles>

cinnamophilin (7)

Fig. 1 Chemical structures of new compounds $1-6$ and 7.

neolignans, cinnamophilin (7), ${ }^{17}$ meso-dihydroguaiaretic acid (8) ${ }^{21,22}$ dehydroguaiaretic acid $(9),{ }^{23}$ oleiferin $\mathrm{D},{ }^{24}$ lyoniresol, ${ }^{25}$ lyoniside, ${ }^{26}$ and $9,9^{\prime}$-O-diferuloyl-seco-isolarici-resinol; ${ }^{27}$ three catechins, (+)-catechin, ${ }^{28} \quad(-)$-epicatechin, ${ }^{28}$ and (+)-epicatechin ${ }^{29}$ three coumarins, scopoletin, ${ }^{30}$ isofraxidin, ${ }^{31}$ and scopolin ${ }^{32}$ ten benzenoids, methyl syringate, ${ }^{33}$ vanillic acid, ${ }^{34}$ syringic acid, ${ }^{34} 3,4,5$-trimethoxyphenyl- $\beta$-D-glucopyranoside, ${ }^{35}$ 5,6-dimeth-oxybenzene-1,3-diol, ${ }^{36}$ $4^{\prime}$-hydroxy-2,3dihydrocinnamic acid penta-cosyl ester, ${ }^{37}(E)$-ferulic acid octacosyl ester ${ }^{38}$ methyl-4-hydroxybenzoate, ${ }^{39}$ homovanillyl alcohol, ${ }^{40}$ and 2,4,6-trimethoxy-phenol; ${ }^{41}$ two amides, $N$-transferuloyltyramine $\mathrm{e}^{42}$ and $\mathrm{N}$-cis-feruloyltyramine; ${ }^{43}$ three isoquinolines: tetrahydroisoquinolinone, ${ }^{44}$ 6,7-dimethoxyisoquinoline,${ }^{45}$ and thalifoline; ${ }^{46}$ two sesquiterpenes, grasshopper ketone ${ }^{47}$ and sesquichamaenol; ${ }^{48}$ and two steroids, $\beta$-sitosterol and $\beta$-sitosteryl glucoside, ${ }^{49}$ respectively.

The pseudomolecular formula of compound 1 was assigned as $\mathrm{C}_{40} \mathrm{H}_{46} \mathrm{O}_{10} \mathrm{Na}$ by HR-ESI-MS analysis which showed an ion adduct peak at $m / z$ 709.2992. Its UV absorption maxima $\left(\lambda_{\max }\right)$ were at 280 and $227 \mathrm{~nm}$ and IR absorption bands at 3393 and $1665 \mathrm{~cm}^{-1}$ were consistent with the presence of 7-oxo-8, $8^{\prime}$ neolignan basic skeleton. ${ }^{50}$ The ${ }^{1} \mathrm{H}$ NMR spectrum (Table 1) revealed one set of ABX-type tri-substituted aromatic ring at $\delta 7.42(\mathrm{br} \mathrm{s}), 7.28(\mathrm{~d}, J=8.4 \mathrm{~Hz})$, and $6.83(\mathrm{~d}, J=8.4 \mathrm{~Hz})$; one set of 1,3,4,5-tetrasubstituted aromatic ring at $\delta 6.73$ (br s) and 6.70 (br s); two methoxy groups at $\delta 3.92$ and 3.86; and one aliphatic $\mathrm{C}_{6}$ fragment evidenced by COSY spectral analysis at $\delta 3.40(\mathrm{~m})$, $2.57(\mathrm{dd}, J=13.5,7.4 \mathrm{~Hz}), 2.51(\mathrm{dd}, J=13.5,7.4 \mathrm{~Hz}), 2.27(\mathrm{~m})$, $1.14(\mathrm{~d}, J=7.8 \mathrm{~Hz}), 0.88(\mathrm{~d}, J=6.6 \mathrm{~Hz})$, respectively. The ${ }^{2} J,{ }^{3} J-$ HMBC correlations from $\mathrm{H}-2(\delta$ 7.42) and $\mathrm{H}-6(\delta$ 7.28) to carbonyl C-7 ( $\delta$ 202.9) suggested the tri-substituted aromatic ring was attached to C-7. The NOESY spectral analysis also exhibited NOE correlations between $\mathrm{H}-2(\delta 7.42)$ and $\mathrm{OCH}_{3}-3(\delta$ 3.92), and between $\mathrm{H}-2^{\prime}(\delta 6.73)$ and $\mathrm{OCH}_{3}-3^{\prime}(\delta 3.86)$, confirmed the locations of methoxy groups. The ECD spectrum which displayed a positive Cotton effect at $277 \mathrm{~nm}$ and a negative Cotton effect at $235 \mathrm{~nm}$ indicated the $8 R$ and $8^{\prime} S$ configurations. ${ }^{17}$ On the basis of above elucidations, the structure of compound 1 was very similar with cinnamophilin (7). ${ }^{17}$ Since the molecular formula $\mathrm{C}_{40} \mathrm{H}_{46} \mathrm{O}_{10}$ revealed the occurrence of two units of $7\left(\mathrm{C}_{20} \mathrm{H}_{24} \mathrm{O}_{5}\right)$ and the minor spectral difference observed in $\mathbf{1}$ was disappearance of $\mathrm{H}-5^{\prime}$, the chemical structure of $\mathbf{1}$ was established as shown (Fig. 1) and the full assignments of ${ }^{1} \mathrm{H}$ and ${ }^{13} \mathrm{C}$ NMR signals (Tables 1 and 2) were determined from the NOESY and HMBC spectral analyses (Fig. 2). Conclusively, compound $\mathbf{1}$ was named trivially as $5,5^{\prime}$ biscinnamophilin.

The UV, IR, ${ }^{1} \mathrm{H}$, and ${ }^{13} \mathrm{C}$ NMR spectral characteristics of 2-5 were similar to those of $\mathbf{1}$. It indicated those compounds also to be lignan derivatives. Both machilupins A (2) and B (3) were obtained as colorless syrup and their molecular formula were determined as $\mathrm{C}_{20} \mathrm{H}_{22} \mathrm{O}_{6}$ by HREIMS analysis. The ${ }^{1} \mathrm{H}$ NMR spectrum of 2 (Table 1) exhibited one set of ABX-type mutually coupled protons at $\delta 7.52(1 \mathrm{H}, \mathrm{d}, J=2.0 \mathrm{~Hz}), 7.21(1 \mathrm{H}, \mathrm{dd}, J=$ $8.0,2.0 \mathrm{~Hz})$, and $6.89(1 \mathrm{H}, \mathrm{d}, J=8.0 \mathrm{~Hz})$; two aromatic singlets at $\delta 6.90$ and 6.74; and two methoxy singlets at $\delta 3.96$ and 3.93, respectively. In addition, one aliphatic 2-methylbutan-3-one fragment $\left[\mathrm{CHCH}\left(\mathrm{CH}_{3}\right) \mathrm{COCH}_{3}\right]$ displayed proton signals at $\delta 3.02(1 \mathrm{H}, \mathrm{dd}, J=13.6,7.2 \mathrm{~Hz}), 2.90(1 \mathrm{H}, \mathrm{tq}, J=7.2,6.8 \mathrm{~Hz})$, $2.60(1 \mathrm{H}, \mathrm{dd}, J=13.6,7.2 \mathrm{~Hz}), 2.03(3 \mathrm{H}, \mathrm{s})$, and $1.03(3 \mathrm{H}, \mathrm{d}, J=$ 
Table $1{ }^{1} \mathrm{H}$ NMR spectroscopic data of compounds $1-5[\delta$ (multi., $\mathrm{J}$ in $\mathrm{Hz}$ )]

\begin{tabular}{|c|c|c|c|c|c|}
\hline Position & $\mathbf{1}^{a}$ & $2^{b}$ & $3^{c}$ & $4^{d}$ & $5^{a}$ \\
\hline 1 & - & - & - & $6.82(\mathrm{br} \mathrm{d}, 7.5)$ & - \\
\hline 2 & $7.42(\mathrm{~s})$ & $6.74(\mathrm{~s})$ & $7.21(\mathrm{~s})$ & $6.69(\mathrm{~d}, 7.5)$ & $6.66(\mathrm{~s})$ \\
\hline 3 & - & - & - & - & - \\
\hline 4 & - & - & - & - & - \\
\hline 5 & $6.83(\mathrm{~d}, 8.4)$ & $6.90(\mathrm{~s})$ & $7.31(\mathrm{~s})$ & $6.99(\mathrm{~d}, 1.8)$ & $7.47(\mathrm{~s})$ \\
\hline 6 & $7.28(\mathrm{~d}, 8.4)$ & - & - & - & - \\
\hline 7 & - & $\begin{array}{l}3.02(\mathrm{dd}, 13.6,7.2) \\
2.60(\mathrm{dd}, 13.6,7.2)\end{array}$ & $10.39(\mathrm{~s})$ & $3.38(\mathrm{~m})$ & $6.45(\mathrm{~s})$ \\
\hline 8 & $3.40(\mathrm{~m})$ & $2.90(\mathrm{tq}, 7.2,6.8)$ & - & $1.76(\mathrm{~m})$ & - \\
\hline 9 & $1.14(\mathrm{~d}, 7.8)$ & $1.03(\mathrm{~d}, 6.8)$ & $2.03(\mathrm{~s})$ & $0.72(\mathrm{~d}, 6.9)$ & $1.77(\mathrm{~s})$ \\
\hline $1^{\prime}$ & - & - & - & - & - \\
\hline $2^{\prime}$ & $6.73(\mathrm{~s})$ & $7.52(\mathrm{~d}, 2.0)$ & $7.10(\mathrm{~d}, 2.0)$ & $7.03(\mathrm{~d}, 1.8)$ & $6.75(\mathrm{~d}, 1.2)$ \\
\hline $3^{\prime}$ & - & - & - & - & - \\
\hline $4^{\prime}$ & - & - & - & - & - \\
\hline $5^{\prime}$ & - & $6.89(\mathrm{~d}, 8.0)$ & $6.73(\mathrm{~d}, 8.4)$ & $6.69(\mathrm{~d}, 7.5)$ & $6.73(\mathrm{~d}, 7.6)$ \\
\hline $6^{\prime}$ & $6.70(\mathrm{~s})$ & $7.21(\mathrm{dd}, 8.0,2.0)$ & $6.92(\mathrm{dd}, 8.4,2.0)$ & $6.82(\mathrm{br} \mathrm{d}, 7.5)$ & $6.77(\mathrm{dd}, 7.6,1.2)$ \\
\hline $7^{\prime}$ & $\begin{array}{l}2.57(\mathrm{dd}, 13.5,7.4) \\
2.51(\mathrm{dd}, 13.5,7.4)\end{array}$ & - & $5.18(\mathrm{~d}, 7.2)$ & $3.57(\mathrm{~d}, 12.0)$ & - \\
\hline $8^{\prime}$ & $2.27(\mathrm{~m})$ & - & $3.74(\mathrm{~m})$ & $2.69(\mathrm{~m})$ & - \\
\hline $9^{\prime}$ & $0.88(\mathrm{~d}, 6.6)$ & $2.03(\mathrm{~s})$ & $1.03(\mathrm{~d}, 6.8)$ & $0.65(\mathrm{~d}, 6.7)$ & $1.67(\mathrm{~s})$ \\
\hline $\mathrm{OCH}_{3}-3$ & $3.92(\mathrm{~s})$ & $3.96(\mathrm{~s})$ & $3.98(\mathrm{~s})$ & $3.83(\mathrm{~s})$ & $3.96(\mathrm{~s})$ \\
\hline $\mathrm{OCH}_{3}-3^{\prime}$ & $3.86(\mathrm{~s})$ & $3.93(\mathrm{~s})$ & $3.81(\mathrm{~s})$ & $3.83(\mathrm{~s})$ & $3.75(\mathrm{~s})$ \\
\hline $\mathrm{OH}$ & $6.06,6.11$ & $5.54,6.10$ & $7.45,8.05$ & $7.24,7.26$ & - \\
\hline
\end{tabular}

${ }^{a}{ }^{1} \mathrm{H}$ NMR data $(\delta)$ were measured in chloroform- $d$ at $300 \mathrm{MHz} .{ }^{b}{ }^{1} \mathrm{H}$ NMR data $(\delta)$ were measured in chloroform- $d$ at $400 \mathrm{MHz} .{ }^{c}{ }^{1} \mathrm{H}$ NMR data $(\delta)$ were measured in acetone- $d_{6}$ at $400 \mathrm{MHz} .{ }^{d}{ }^{1} \mathrm{H}$ NMR data $(\delta)$ were measured in acetone- $d_{6}$ at $300 \mathrm{MHz}$.

$6.8 \mathrm{~Hz}$ ), and its arrangement was evidenced by COSY and HMBC analysis. In the HMBC analysis, there were correlations from $\mathrm{H}$ 2 to $\mathrm{C}-7$, from $\mathrm{H}-5$ to $\mathrm{C}-7^{\prime}$, from $\mathrm{H}-2^{\prime}$ to $\mathrm{C}-7^{\prime}$, and from $\mathrm{CH}_{3}-9^{\prime}$ to $\mathrm{C}-8^{\prime}$. The NOESY spectrum also showed NOE correlations of $\mathrm{H}^{-}$ $2 / \mathrm{OCH}_{3}-3$ and $\mathrm{H}-2^{\prime} / \mathrm{OCH}_{3}-3^{\prime}$. Therefore, the chemical structure of 2 was constructed as shown (Fig. 1). The ${ }^{13} \mathrm{C}$ spectrum of 3

Table $2{ }^{13} \mathrm{C}$ NMR spectroscopic data of compounds $1-5$

\begin{tabular}{lrrrrr}
\hline & $\mathbf{1}^{a}$ & \multicolumn{1}{c}{$\mathbf{2}^{b}$} & \multicolumn{1}{c}{$\mathbf{3}^{c}$} & \multicolumn{1}{c}{$\mathbf{4}^{d}$} & \multicolumn{1}{c}{$\mathbf{5}^{b}$} \\
\hline 1 & 129.5 & 131.3 & 128.0 & 121.2 & 133.3 \\
2 & 110.3 & 113.4 & 116.9 & 115.1 & 107.7 \\
3 & 146.7 & 146.6 & 153.2 & 148.1 & 151.9 \\
4 & 150.1 & 142.9 & 145.8 & 145.4 & 144.9 \\
5 & 113.7 & 115.8 & 111.0 & 112.3 & 112.8 \\
6 & 123.3 & 132.1 & 141.1 & 138.3 & 121.2 \\
7 & 202.9 & 36.2 & 190.9 & 66.9 & 121.4 \\
8 & 42.8 & 48.9 & 211.6 & 36.6 & 145.4 \\
9 & 11.6 & 16.5 & 28.8 & 9.9 & 19.8 \\
$1^{\prime}$ & 132.5 & 130.8 & 134.9 & 137.6 & 132.6 \\
$2^{\prime}$ & 111.3 & 111.2 & 113.0 & 112.2 & 109.3 \\
$3^{\prime}$ & 147.1 & 147.6 & 148.3 & 148.1 & 146.5 \\
$4^{\prime}$ & 141.0 & 150.4 & 146.1 & 145.4 & 144.7 \\
$5^{\prime}$ & 124.3 & 113.6 & 115.8 & 115.1 & 114.2 \\
$6^{\prime}$ & 123.8 & 126.5 & 121.0 & 121.4 & 119.5 \\
$7^{\prime}$ & 41.5 & 196.3 & 46.6 & 56.7 & 200.6 \\
$8^{\prime}$ & 37.7 & 212.6 & 52.0 & 36.6 & 55.0 \\
$9^{\prime}$ & 15.5 & 29.1 & 16.8 & 12.1 & 22.0 \\
OCH $_{3}-3$ & 56.0 & 56.1 & 56.5 & 56.2 & 56.0 \\
OCH $_{3}{ }^{\prime} 3^{\prime}$ & 56.1 & 56.2 & 56.3 & 56.2 & 55.8
\end{tabular}

${ }^{a}{ }^{13} \mathrm{C}$ NMR data $(\delta)$ were measured in chloroform- $d$ at $75 \mathrm{MHz} .{ }^{b}{ }^{13} \mathrm{C}$ NMR data $(\delta)$ were measured in chloroform- $d$ at $100 \mathrm{MHz} .{ }^{c{ }^{13}} \mathrm{C}$ NMR data $(\delta)$ were measured in acetone- $d_{6}$ at $100 \mathrm{MHz} .{ }^{d{ }^{13} \mathrm{C} \text { NMR data }(\delta)}$ were measured in acetone- $d_{6}$ at $75 \mathrm{MHz}$.
(Table 2) combined with HSQC NMR analysis revealed 20 signals, of which were two carbonyls at $\delta 211.6$ and 190.9, twelve aromatic carbons, two methyls ( $\delta 28.8$ and 16.8), and two methoxy groups ( $\delta 56.5$ and 56.3 ), respectively. Not only the same molecular formula, but the ${ }^{1} \mathrm{H}$ NMR spectral signals of 3 were also similar to those of 2, including three ABX-type mutually coupled protons, two aromatic singlets, two methoxy singlets, and one 2-methylbutan-3-one aliphatic fragment. The observed difference was one more formyl group $\delta 10.39(1 \mathrm{H}, \mathrm{s})$ in 3. The HMBC spectrum of 3 displayed correlations from $\mathrm{H}-2$ to $\mathrm{C}-7$, from $\mathrm{H}-5$ to $\mathrm{C}^{-} 7^{\prime}$, from $\mathrm{H}-2^{\prime}$ to $\mathrm{C}^{-} 7^{\prime}$, from $\mathrm{H}-6^{\prime}$ to $\mathrm{C}-7^{\prime}$, from $\mathrm{H}-7^{\prime}$ to $\mathrm{C}-8$ and $\mathrm{C}-8^{\prime}$, and from $\mathrm{CH}_{3}-9^{\prime}$ to $\mathrm{C}-8$ and $\mathrm{C}-8^{\prime}$, respectively. NOESY analysis of 3 determined the methoxy function substitutions and finally furnished the planar structure assignment of 3 (Fig. 1).

Machilupin C (4) was afforded as optically active colorless powder with a molecular formula of $\mathrm{C}_{20} \mathrm{H}_{26} \mathrm{O}_{5}$ determined by HREIMS analysis. Proton signals including two sets of ABX-type mutually coupled protons at $\delta 7.03(1 \mathrm{H}, \mathrm{d}, J=1.8 \mathrm{~Hz}), 6.99(1 \mathrm{H}$, $\mathrm{d}, J=1.8 \mathrm{~Hz}), 6.82(2 \mathrm{H}$, br d, $J=7.5 \mathrm{~Hz})$, and $6.69(2 \mathrm{H}, \mathrm{d}, J=7.5$ $\mathrm{Hz}$; two methoxy singlets at $\delta 3.83$; and one 2,3-dimethylbutan4-ol aliphatic fragment $\left[\mathrm{CHCH}\left(\mathrm{CH}_{3}\right) \mathrm{CH}\left(\mathrm{CH}_{3}\right) \mathrm{CH}_{2} \mathrm{OH}\right]$ evidenced by COSY analysis at $\delta 3.57(1 \mathrm{H}, \mathrm{d}, J=12.0 \mathrm{~Hz}), 3.38(2 \mathrm{H}$, $\mathrm{m}), 2.69(1 \mathrm{H}, \mathrm{m}), 1.76(1 \mathrm{H}, \mathrm{m}), 0.72(3 \mathrm{H}, \mathrm{d}, J=6.9 \mathrm{~Hz})$, and 0.65 $(3 \mathrm{H}, \mathrm{d}, J=6.7 \mathrm{~Hz})$, were appeared in the ${ }^{1} \mathrm{H}$ NMR spectrum of 4 . Analysis of its HMBC spectrum (Fig. 2) revealed correlations from $\mathrm{H}-1$ to $\mathrm{C}-7^{\prime}$, from $\mathrm{H}-5$ to $\mathrm{C}-7^{\prime}$, from $\mathrm{H}-2^{\prime}$ to $\mathrm{C}-7^{\prime}$, and from $\mathrm{H}-$ $6^{\prime}$ to $\mathrm{C}-7^{\prime}$ determined that the aliphatic moiety was connected through $\mathrm{C}-7^{\prime}$ with $\mathrm{C}-6$ and $\mathrm{C}-\mathrm{1}^{\prime}$ of the aromatic rings. The NOESY spectrum exhibited NOE correlations of $\mathrm{H}-2 / \mathrm{OCH}_{3}-3$ and $\mathrm{H}-2^{\prime}$ / $\mathrm{OCH}_{3}-3^{\prime}$ determined the locations of methoxy groups. The ECD 


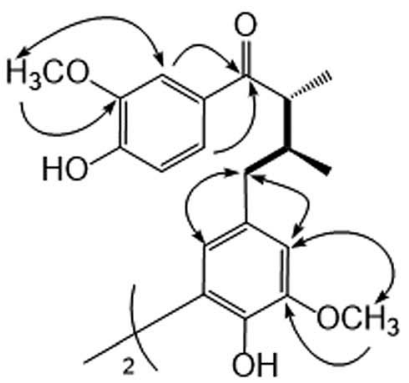

1

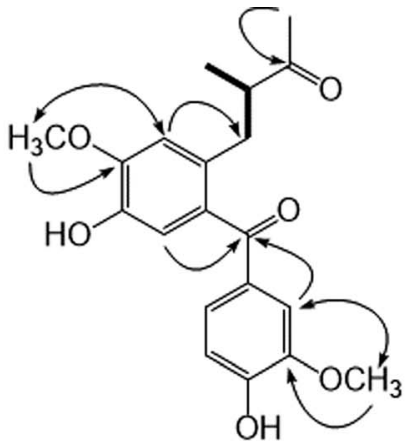

2

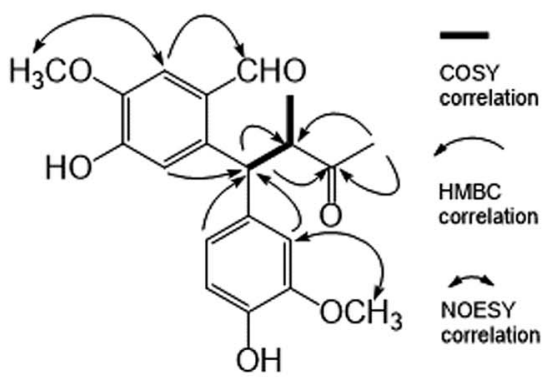

3

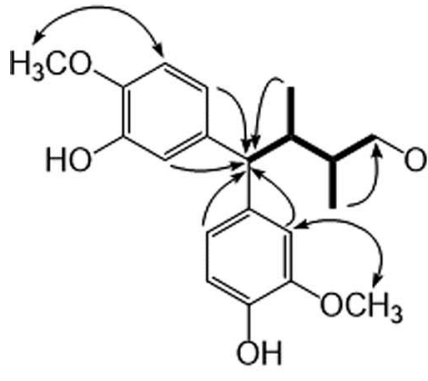

4

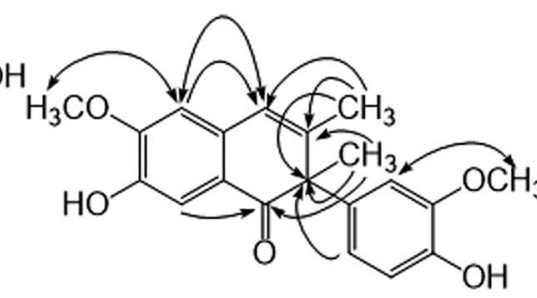

5

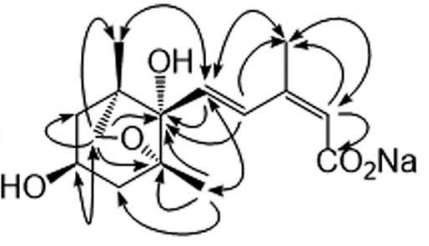

6

Fig. 2 Significant COSY, HMBC and NOESY correlations of 1-6.

spectrum of 4 exhibited a positive Cotton effect at $276 \mathrm{~nm}$ and a negative Cotton effect at $235 \mathrm{~nm}$ also indicated the $8 R$ and $8^{\prime} S$ configurations. Consequently, the chemical structure of 4 was established as shown (Fig. 1).

Machilutone A (5) was obtained as colorless syrup with the pseudomolecular formula of $\mathrm{C}_{20} \mathrm{H}_{20} \mathrm{O}_{5} \mathrm{Na}$ determined by HRESIMS ion peak at $m / z$ 363.1206, representing eleven unsaturation equivalents which was one more than that of 2. Although the ${ }^{1} \mathrm{H}$ NMR spectrum of 5 also showed one set of ABX-type mutually coupled protons at $\delta 6.77(1 \mathrm{H}, \mathrm{dd}, J=7.6,1.2 \mathrm{~Hz})$, $6.75(1 \mathrm{H}, \mathrm{d}, J=1.2 \mathrm{~Hz})$, and $6.73(1 \mathrm{H}, \mathrm{d}, J=7.6 \mathrm{~Hz})$; two aromatic singlets at $\delta 7.47$ and 6.66; and two methoxy singlets at $\delta 3.96$ and 3.75 , respectively, some more spectral differences would be observed. One more aromatic singlet at $\delta 6.45$ and two methyl singlets at $\delta 1.77$ and 1.67 appeared in its ${ }^{1} \mathrm{H}$ NMR spectrum. However, there were not any signals representing the aliphatic moieties commonly found in 2-4. These NMR spectral and mass spectrometric information suggested the change of the side chain in 5. Analysis of its HMBC spectrum (Fig. 2) displayed the correlations from $\mathrm{H}-2$ to $\mathrm{C}-7$, from $\mathrm{H}-5$ to $\mathrm{C}-7^{\prime}$, from $\mathrm{CH}_{3}-9$ to $\mathrm{C}-7, \mathrm{C}-8$, and $\mathrm{C}-8^{\prime}$, from $\mathrm{H}-2^{\prime}$ to $\mathrm{C}-8^{\prime}$, from $\mathrm{H}-6^{\prime}$ to $\mathrm{C}-8^{\prime}$, and from $\mathrm{CH}_{3}-9^{\prime}$ to $\mathrm{C}-8, \mathrm{C}-7^{\prime}$, and $\mathrm{C}-8^{\prime}$, respectively. NOESY analysis also located the methoxy groups at C-3 and C- $3^{\prime}$. Therefore, all the spectral evidences supported the structure of 5 as shown (Fig. 1) and the full assignments of ${ }^{1} \mathrm{H}$ and ${ }^{13} \mathrm{C}$ NMR signals were completed by the assistance of 2D NMR experiments. The chemical structure of $\mathbf{5}$ was characterized as unprecedented carbon skeletons from the natural sources.

Machilusoxide A (6) was isolated as optically active colorless syrup. The HRESIMS analytical result of $\mathbf{6}$ exhibited a pseudomolecular ion peak at $m / z 281.1382$. The UV spectrum showed the absorption maxima at 273 and $249 \mathrm{~nm}$. The IR spectrum indicated the presence of hydroxyl $\left(3507 \mathrm{~cm}^{-1}\right)$ and carbonyl groups $\left(1713 \mathrm{~cm}^{-1}\right)$. The ${ }^{1} \mathrm{H}-\mathrm{NMR}$ spectrum exhibited signals for one vinyl proton at $\delta 5.85(1 \mathrm{H}, \mathrm{s})$, two trans olefinic protons at $\delta 7.70(1 \mathrm{H}, \mathrm{d}, J=16.2 \mathrm{~Hz})$ and $6.23(1 \mathrm{H}, \mathrm{d}, J=16.2 \mathrm{~Hz})$, three methyl singlets at $\delta 1.98,1.15$, and 0.92 , one oxymethine at $\delta 4.09(1 \mathrm{H}, \mathrm{tdd}, J=10.8,6.6,3.3 \mathrm{~Hz})$, two sets of methylene protons at $\delta 2.04(2 \mathrm{H}, \mathrm{m})$ and $1.83(2 \mathrm{H}, \mathrm{m})$, respectively. The ${ }^{13} \mathrm{C}$ NMR spectrum exhibited a carboxylic acid group at $\delta 175.4$; four olefinic carbons at $\delta 139.7,132.6,129.5$, and 128.1; and four oxygenated carbons at $\delta 87.2,82.7,76.8$, and 63.7. The above spectral data evidenced the structure of 6 was similar to dihydrophaseic acid, ${ }^{51}$ an abscisic acid (ABA) derivative commonly occurred in the phytohormones, which played the key role in biotic and abiotic stress responses. ${ }^{52}$ The substitution pattern was further confirmed through the HMBC experiment, in which displayed the ${ }^{2} J{ }^{3} J$-HMBC correlations from $\mathrm{H}-2$ to C-1 and C-6; from $\mathrm{H}-4$ to $\mathrm{C}-1^{\prime}$ and $\mathrm{CH}_{3}-6$; from $\mathrm{H}-5$ to $\mathrm{C}-1^{\prime}$; from $\mathrm{CH}_{3}-6$ to $\mathrm{C}-2$ and $\mathrm{C}-4$; from $\mathrm{CH}_{3}-7^{\prime}$ to $\mathrm{C}-1^{\prime}, \mathrm{C}-2^{\prime}$, and $\mathrm{C}-3^{\prime}$; and from $\mathrm{CH}_{2}-8^{\prime}$ to $\mathrm{C}-1^{\prime}, \mathrm{C}-2^{\prime}, \mathrm{C}-5^{\prime}, \mathrm{C}-6^{\prime}$, and $\mathrm{CH}_{3}-9^{\prime}$, respectively. The relative stereochemistry was determined by the NOESY analysis which revealed NOE correlations of $\mathrm{H}-2 / \mathrm{CH}_{3}-6, \mathrm{H}-5 / \mathrm{CH}_{3}-6, \mathrm{H}-5 / \mathrm{CH}_{3}-7^{\prime}$, $\mathrm{H}-5 / \mathrm{CH}_{3}-9^{\prime}$, and $\mathrm{H}-4^{\prime} / \mathrm{CH}_{2}-8^{\prime}$ (Fig. 2). Therefore, the side chain at $\mathrm{C}-1^{\prime}$, the hydroxyl groups at $\mathrm{C}-4^{\prime}$, and methyl substituent at $\mathrm{C}-2^{\prime}$ and $C-6^{\prime}$ all were in cis configuration. The C-2/C-3 carboncarbon double bond was in $Z$ and the C-2-C-5 fragment was in $S$ trans configurations, respectively. The presence of $\mathbf{6}$ as a sodium salt was evidenced by the ICPMS analytical data, in which $\left[\mathrm{Na}^{+}\right]$ was equal to $1 \mathrm{ppm}$ in the $10 \mathrm{ppm}$ sample. Comparison of the spectral data of 6 with that of dihydrophaseic acid, ${ }^{51}$ upfield shift of H-4 ( $\delta 7.96$ to 7.70) further supported the occurrence of 
sodium carboxylate. After acidification of $\mathbf{6}$, the resulted sample produced totally the same ${ }^{1} \mathrm{H}$-NMR spectrum as that of dihydrophaseic acid. ${ }^{51}$ Conclusively, the structure of 6 was assigned as sodium dihydrophaseate based on the above-mentioned elucidations.

Dehydroguaiaretic acid (9) was obtained as colorless needles. The ${ }^{1} \mathrm{H}$-NMR spectrum exhibited signals for two aromatic singlets at $\delta 7.50$ and 7.06; one set of ABX system coupled protons at $\delta 7.03(1 \mathrm{H}, \mathrm{d}, J=8.4 \mathrm{~Hz}), 6.74(1 \mathrm{H}, \mathrm{dd}, J=8.4,2.0$ $\mathrm{Hz})$, and $6.72(1 \mathrm{H}, \mathrm{d}, J=2.0 \mathrm{~Hz})$; two methoxy groups at $\delta 4.00$ $(3 \mathrm{H}, \mathrm{s})$ and $3.86(3 \mathrm{H}, \mathrm{s})$; and two methyl singlets at $\delta 2.45(3 \mathrm{H})$ and $2.13(3 \mathrm{H})$. These spectral data were coincided well with those reported for cinnamophilin A (10).${ }^{53}$ However, with careful evaluation of all the ${ }^{1} \mathrm{H}$ and ${ }^{13} \mathrm{C}$ NMR data (Table 3 ), it should be revised as dehydroguaiaretic acid (9) which had already been published in the literature. ${ }^{23,54}$

The plausible biosynthetic mechanism of above-mentioned new lignans was proposed as shown (Fig. 3). Cyclization of the dibenzylbutane type lignan meso-dihydroguaiaretic acid (8) resulted in a aryltetralin intermediate 11. Successive $7^{\prime}, 8^{\prime}$ cleavage of 11 and further oxidation of $\mathrm{C}-7^{\prime}$ and $\mathrm{C}-8^{\prime}$ in 12 yielded machilupin A (2). In comparison, 7,8-cleavage of the cyclic intermediate 11 and further oxidation of C-7 and C-8 in 13 produced machilupin B (3). 1,7-Cleavage of aryltetralin intermediate $\mathbf{1 1}$ and hydroxylation of the terminal alkene in $\mathbf{1 4}$

Table 3 Comparison of ${ }^{1} \mathrm{H}$ and ${ }^{13} \mathrm{C}$ NMR spectroscopic data of dehydroguaiaretic acid $(9)^{23,54}$ and cinnamophilin $\mathrm{A}(10)^{53}$
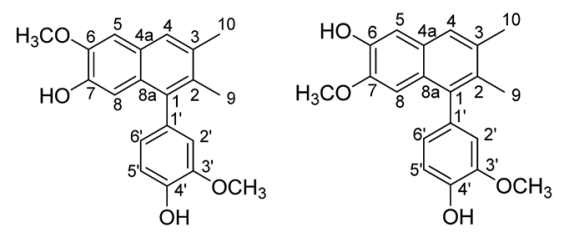

\begin{tabular}{|c|c|c|c|}
\hline \multirow[b]{2}{*}{ Position } & \multicolumn{2}{|c|}{ Dehydroguaiaretic acid (9) } & \multirow{2}{*}{$\begin{array}{l}\text { Cinnamophilin A (10) } \\
\delta_{\mathrm{H}}(\text { multi., } J \text { in } \mathrm{Hz})\end{array}$} \\
\hline & $\delta_{\mathrm{C}}$ & $\begin{array}{l}\delta_{\mathrm{H}} \\
\text { (multi., } J \text { in } \mathrm{Hz} \text { ) }\end{array}$ & \\
\hline 1 & 138.0 & - & - \\
\hline 2 & 133.4 & - & - \\
\hline 3 & 132.6 & - & - \\
\hline 4 & 126.7 & $7.50(\mathrm{~s})$ & $7.49(\mathrm{~s})$ \\
\hline $4 a$ & 129.0 & - & - \\
\hline 5 & 115.2 & $7.06(\mathrm{~s})$ & $7.05(\mathrm{~s})$ \\
\hline 6 & 147.5 & - & - \\
\hline 7 & 145.6 & - & - \\
\hline 8 & 109.5 & $6.82(\mathrm{~s})$ & $6.81(\mathrm{~s})$ \\
\hline $8 \mathrm{a}$ & 128.3 & - & - \\
\hline 9 & 18.3 & $2.13(\mathrm{~s})$ & $2.11(\mathrm{~s})$ \\
\hline 10 & 21.9 & $2.45(\mathrm{~s})$ & $2.45(\mathrm{~s})$ \\
\hline $1^{\prime}$ & 134.1 & - & - \\
\hline $2^{\prime}$ & 123.9 & $6.72(\mathrm{~d}, 2.0)$ & $6.73(\mathrm{~d}, 1.6)$ \\
\hline $3^{\prime}$ & 147.3 & - & - \\
\hline $4^{\prime}$ & 145.3 & - & - \\
\hline $5^{\prime}$ & 105.9 & $7.03(\mathrm{~d}, 8.4)$ & $7.02(\mathrm{~d}, 8.0)$ \\
\hline $6^{\prime}$ & 113.5 & $6.74(\mathrm{dd}, 8.4,2.0)$ & $6.72(\mathrm{dd}, 8.0,1.6)$ \\
\hline $\mathrm{OCH}_{3}-6$ & 56.7 & $4.00(\mathrm{~s})$ & $4.00(\mathrm{~s})$ \\
\hline $\mathrm{OCH}_{3}-3^{\prime}$ & 56.8 & $3.86(\mathrm{~s})$ & $3.85(\mathrm{~s})$ \\
\hline
\end{tabular}

afforded machilupin C (4). Machilutone A (5) was resulted from the phenyl migration from $\mathrm{C}-7^{\prime}$ to $\mathrm{C}-8^{\prime}$ of cyclic intermediate $\mathbf{1 1}$ and further oxidation on $\mathrm{C}-\mathbf{7}^{\prime}$ and C-7/C-8 of $\mathbf{1 5}$.

Among these isolated compounds, several lignans exhibited the significant contents in the stem extracts of $M$. philippinensis, such as cinnamophilin (7) and meso-dihydroguaiaretic acid (8). In the previous reports, cinnamophilin (7) exhibited the ability to block $\mathrm{Na}^{+}$and $\mathrm{Ca}^{2+}$ inward currents in rat cardiac cells, and also been demonstrated to protect against ischemic-reperfusion injury of muscle in vivo. ${ }^{7}$ In addition, it also offered prolonged neuro-protection against gray and white matter damage and improved functional and electrophysiological outcomes after transient focal cerebral ischemia. ${ }^{9}$ To further evaluate the neuroprotective potential of cinnamophilin (7), its bioactivity was examined in the primary cortical neurons culture by glutamate-induced oxidative stress assay. ${ }^{55}$ Both the trypan blue stain and lactate dehydrogenase release data displayed that 7 was effective against the glutamate induced excitotoxicity, with the $\mathrm{IC}_{50}$ values of $4.3 \pm 2.0$ and $3.5 \pm 1.7 \mu \mathrm{M}$, respectively (Fig. 4-7). These experimental results supported the further development of the stem extracts of $M$. philippinensis and related principles as the natural neuroprotective lead compounds.

\section{Experimental}

\section{General experimental procedures}

Melting points were determined using Yanagimoto MP-S3 micro melting point apparatus without correction. Optical rotations were measured using a JASCO DIP-370 digital polarimeter. UV spectra were examined at room temperature on a Hitachi UV-3210 spectrophotometer. IR spectra were obtained with a Shimadzu FTIR Prestige-21 spectrophotometer. ${ }^{1} \mathrm{H}$ and ${ }^{13} \mathrm{C}$ NMR spectra were recorded on the Bruker Advance 300 and AMX-400 NMR spectrometers. Chemical shifts are shown in $\delta$ values (ppm) with tetramethylsilane as an internal standard. The EIMS and HREIMS were measured on a VG 70-250S mass spectrometer, and the ESIMS and HRESIMS were taken on a Bruker APEX II FT-MS spectrometer (positive-ion mode). Inductively coupled plasma (ICP) MS was recorded on a Thermo-Element XR ICPMS spectrometer, and three elements (Na, K, Ca) were examined for their concentration by comparison with the standard curves. ECD spectra were obtained on a JASCO J-720 spectrometer. X-ray single crystal diffraction was measured in National Chung-Hsing University with a Bruker D8 Venture diffractometer with a Photon 100 CMOS detector system equipped with a $\mathrm{Cu}$ Incoatec $\mathrm{I} \mu \mathrm{S}$ microfocus source $(\lambda=$ $1.54178 \AA$ ). Column chromatography (CC) was performed on silica (70-230 mesh and 230-400 mesh, Merck) and Diaion HP20 (Mitsubishi) gels. Preparative thin-layer chromatography (pTLC) was conducted on Merck precoated silica gel 60 F254 plates, using UV light to visualize the spots. High-performance liquid chromatography (HPLC) was performed on a Shimadzu LC-20AT series pumping system equipped with a Shimadzu SPD-20A UV-Vis detector, and a SIL-10AF autosampling system at ambient temperature and a RP-18 column (Ascentis C18, 5 $\mu \mathrm{m}, 10 \mathrm{~mm} \times 25 \mathrm{~cm})$. 


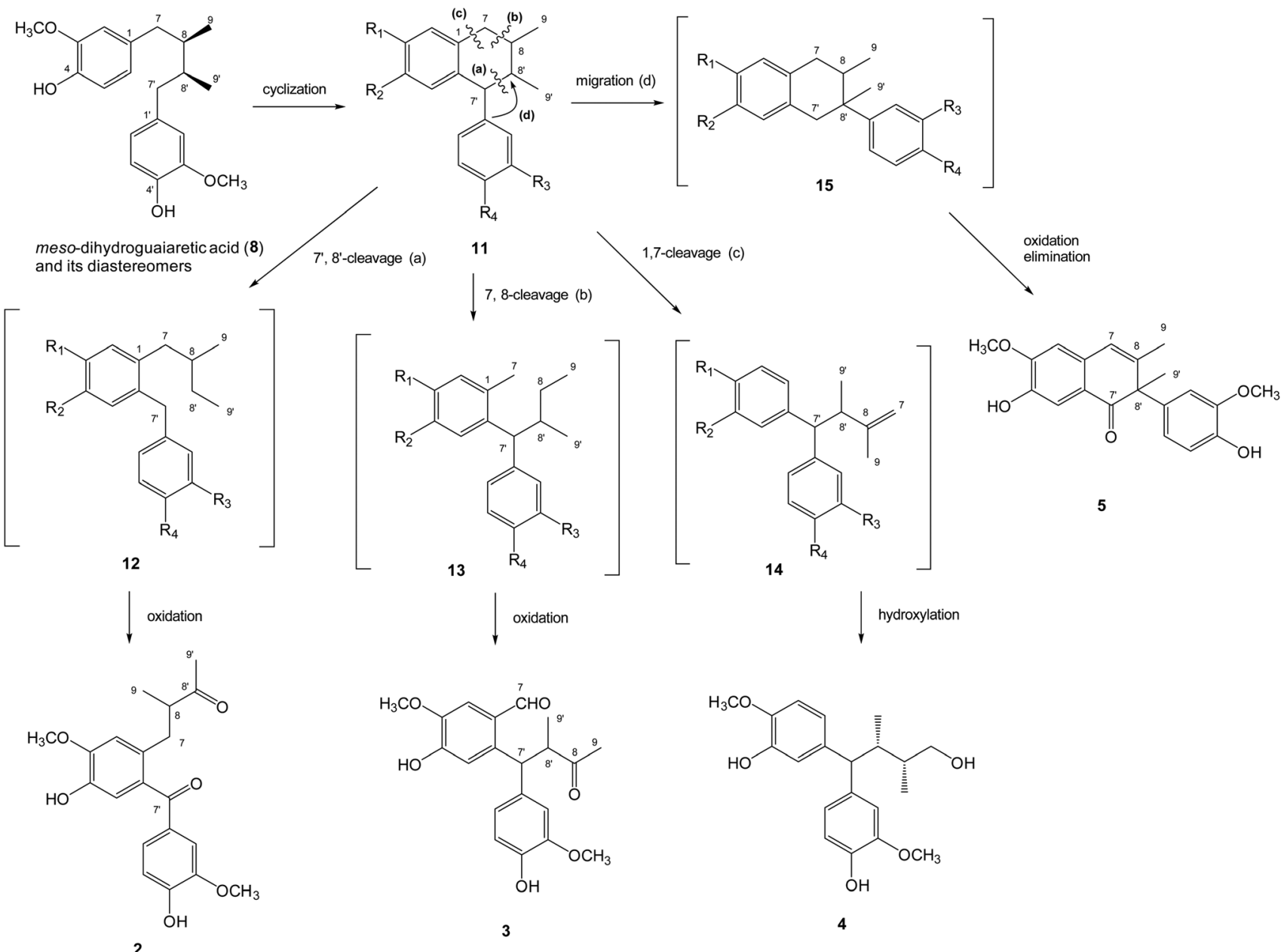

Fig. 3 The plausible biosynthetic mechanism of new lignans 2-5.

\section{Plant material}

The stems of $M$. philippinensis Merr. was collected in Pingtung County, Taiwan, in July 2005 and identified by Prof. ChangSheng Kuoh, Department of Life Science, National Cheng Kung University (NCKU), Tainan, Taiwan. A voucher specimen (TSWu 200507001) has been deposited in the Herbarium of School of Pharmacy, NCKU.

\section{Extraction and isolation}

The dried stems of $M$. philippinensis $(34 \mathrm{~kg}$ ) were powdered and consecutively extracted with methanol. The methanol was removed and evaporated in vacuo to yield dried extract $(1.9 \mathrm{~kg})$. The syrup was suspended in water and then extracted successively with chloroform and $n$-butanol to produce the chloroform (600 g), n-butanol (B, $500 \mathrm{~g}$ ), and water (800 g) layers, respectively. The chloroform layer was further acidified by $2 \% \mathrm{HCl}_{(\mathrm{aq})}$ and the combined organic solvent was concentrated to afford non-alkaloid chloroform fraction (NC, $570 \mathrm{~g}$ ). The acidic hydrophilic layer was neutralized by ammonia water and the $\mathrm{pH}$ value was adjusted to about 10 . Again this aqueous solution was extracted by chloroform to yield alkaloid chloroform fraction (AC, $10 \mathrm{~g}$ ) and residue (10 g) which was combined with water fraction to form water solubles (W, $810 \mathrm{~g})$. The resulted $\mathrm{NC}$ and AC layers were subjected to silica gel column chromatography $\left(\mathrm{SiO}_{2} \mathrm{CC}\right)$ eluted with step-gradient $n$-hexane/ethyl acetate $(9: 1$ to $1: 1)$ and chloroform/methanol ( $9: 1$ to $1: 1)$ to afford eleven (NC-1 to -11) and eight (AC-1 to -8) fractions. The $n$-butanol layer and water solubles were purified on Diaion HP-20 CC with stepgradient water/methanol (9:1 to $1: 9)$ to give six (B-1 to -6) and six (W-1 to -6$)$ fractions, respectively. Further purifications were performed on the fractions displayed significant spots based on the TLC profiles.

Fractions NC-4, -5, and -6 were isolated by $\mathrm{SiO}_{2} \mathrm{CC}$ eluted with a solvent mixture of $n$-hexane/ethyl acetate (15:1 to $1: 1$ ) and further recrystallization of the resulting subfractions of NC4 and -5 afforded 4 -hydroxy-2,3-dihydrocinnamic acid pentacosyl ester $(4.2 \mathrm{~g})$. Subfraction NC-6-1 was recrystallized with chloroform/methanol to produce $\beta$-sitosterol (3.68 g). NC-6-2 was resolved on $\mathrm{SiO}_{2} \mathrm{CC}$ eluted with a step gradient mixture of $n$-hexane/acetone (100:1 to $1: 1$ ) and further purification of the resulting minor fractions with pTLC to yield oleiferin $\mathrm{D}(0.6$ $\mathrm{mg})$, methyl-4-hydroxybenzoate $(0.4 \mathrm{mg})$, and sesquichamaenol (6.2 mg). Fraction NC-7 was purified by $\mathrm{SiO}_{2} \mathrm{CC}$ eluted with a solvent mixture of $n$-hexane/acetone $(5: 1$ to $1: 1)$ to afford five subfractions. NC-7-2 was recrystallized with chloroform/ 

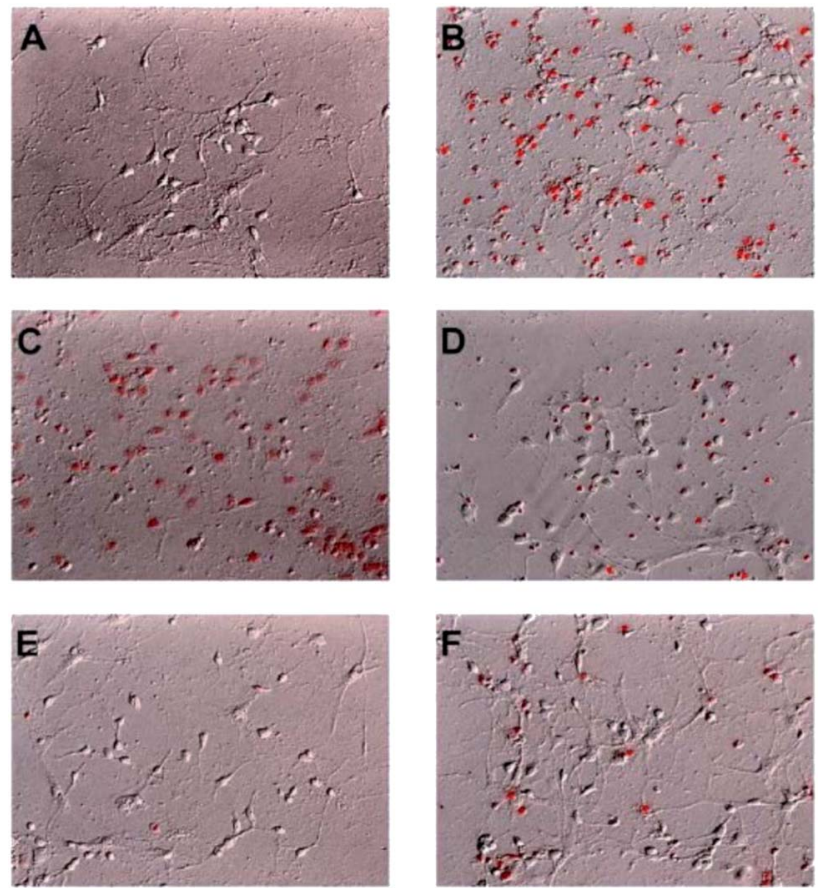

Fig. 4 Cinnamophilin (7) reduced the glutamate-stimulated neuronal death in the concentration-dependent manner. PI uptake in cell culture was shown. (A) Primary cortical neurons treated DMSO 20 min then replaced with fresh medium as control. (B) Primary cortical neurons treated DMSO, (C) 1, (D) 3, (E) $10 \mu \mathrm{M} 7$ and (F) $20 \mu \mathrm{M} \mathrm{MK-801,}$ after 20 min added $300 \mu \mathrm{M}$ glutamate for $6 \mathrm{~h}, n=6$.

acetone to produce dehydroguaiaretic acid (9) (1.24 g). NC-7-4 was isolated on $\mathrm{SiO}_{2} \mathrm{CC}$ eluted with a step gradient mixture of $n$-hexane/acetone $(10: 1$ to $1: 1)$ and the resulting minor fractions were resolved by pTLC eluted with solvent mixtures of $n$ hexane/ethyl acetate $(3: 1)$ and $n$-hexane/acetone $(3: 1)$ to afford methyl syringate $(0.7 \mathrm{mg})$, machilupin A (2) $(2.6 \mathrm{mg})$, machilupin B (3) (3.8 mg), respectively. Fractions NC-8 and -9 were isolated by $\mathrm{SiO}_{2} \mathrm{CC}$ eluted with a solvent mixture of $n$ hexane/ethyl acetate $(3: 1$ to $1: 1)$ and further resolved by recrystallization, repeated $\mathrm{SiO}_{2} \mathrm{CC}$, and pTLC for the resulting subfractions produced cinnamophilin (7) (70.9 g), $(E)$-ferulic acid octacosyl ester (7.6 mg), 5,5'-biscinnamophilin (1) (2.2 mg), scopoletin $(4.3 \mathrm{mg})$, and isofraxidin $(2.4 \mathrm{mg})$, respectively. Fraction NC-10 was carried out $\mathrm{SiO}_{2} \mathrm{CC}$ purification eluted with a solvent mixture of chloroform/methanol $(19: 1$ to $1: 1)$ to afford five subfractions. NC-10-2 was recrystallized with chloroform/acetone to yield 9,9'-O-diferuloyl-seco-isolariciresinol $(275.5 \mathrm{mg})$. NC-10-3 was isolated by $\mathrm{SiO}_{2} \mathrm{CC}$ eluted with a solvent mixture of chloroform/methanol $(9: 1$ to $1: 1)$ and further resolved by pTLC eluted with chloroform/methanol $(6: 1)$ to result in machilupin C (4) $(4.5 \mathrm{mg}), N$-trans-feruloyltyramine $(0.8 \mathrm{mg})$, and $N$-cis-feruloyltyramine $(0.6 \mathrm{mg})$. Recrystallization of the last fraction NC-11 afforded $\beta$-sitosteryl3-O- $\beta$-glucopyranoside $(2.7 \mathrm{~g})$.

Most of the alkaloid chloroform fractions (AC-2 to -7) were further separated by $\mathrm{SiO}_{2} \mathrm{CC}$. Fractions AC-2 and -3 were eluted by $n$-hexane/acetone $(6: 1)$ and further resolved by
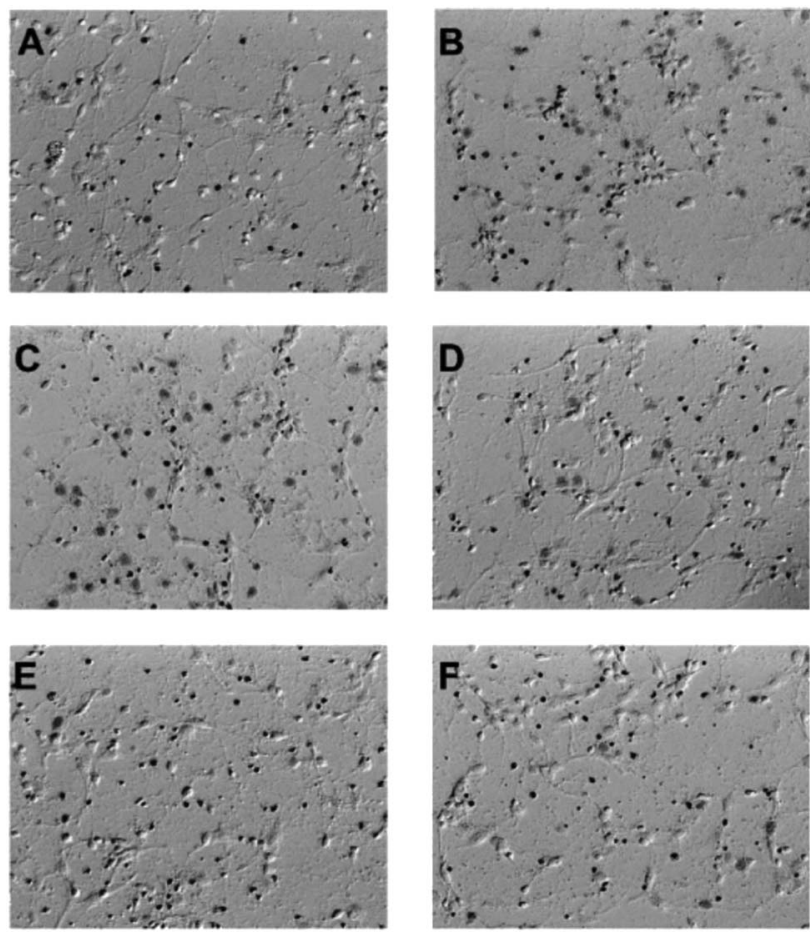

Fig. 5 Cinnamophilin (7) reduced the glutamate-stimulated neuronal death in the concentration-dependent manner. Trypan blue uptake in cell culture was shown. (A) Primary cortical neurons treated DMSO $20 \mathrm{~min}$ then replaced with fresh medium as control. (B) Primary cortical neurons treated DMSO, (C) 1, (D) 3, (E) $10 \mu \mathrm{M} 7$ and (F) $20 \mu \mathrm{M}$ MK-801, after 20 min added $300 \mu$ M glutamate for 6 h, $n=4$.

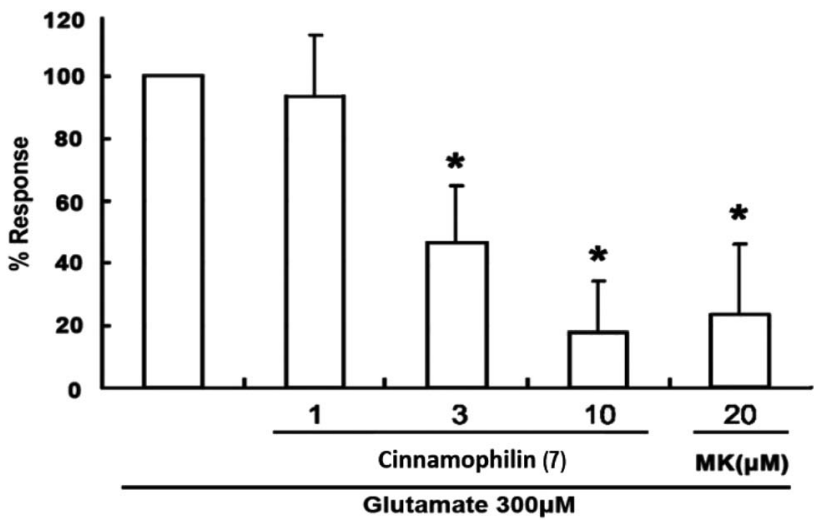

Fig. 6 Cinnamophilin (7) reduced the glutamate-stimulated neuronal death in the concentration-dependent manner. Trypan blue in cell released out by treating $1 \%$ Triton X-100 and measured the absorbance at $600 \mathrm{~nm}$. Data are expressed as percentage of control optical density (OD) values. Bars represent the mean $\pm \mathrm{SD}, n=4$. * Significantly different from activated control cultures (one-way ANOVA followed by LSD test, $P<0.05)$.

recrystallization of the resulting subfractions yielded mesodihydroguaiaretic acid (8) $(6.2 \mathrm{mg})$. Fraction AC-4 was eluted by $n$-hexane/acetone ( $5: 1)$ to afford five subfractions. AC-4-2 was further resolved by repeated $\mathrm{SiO}_{2} \mathrm{CC}$ and pTLC to produce machilutone A (5) $(3.1 \mathrm{mg})$. AC-4-4 was purified by pTLC to 


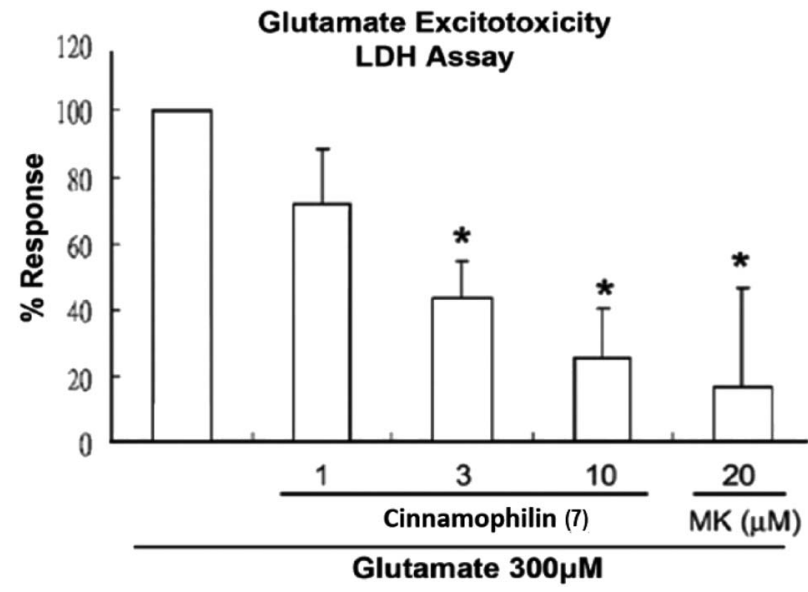

Fig. 7 Cinnamophilin (7) reduced the glutamate-stimulated neuronal death in the concentration-dependent manner. After primary cortical neurons in culture were treated $7(1,3$ and $10 \mu \mathrm{M})$ or MK-801 $(20 \mu \mathrm{M})$ and all were exposed to glutamate $(300 \mu \mathrm{M})$, culture medium was removed and then sampled for $\mathrm{LDH}$ by measuring the absorbance at $490 \mathrm{~nm}$. Data are expressed as percentage of control optical density (OD) values. Bars represent the mean $\pm S D, n=6$. *Significantly different from activated control cultures (one-way ANOVA followed by LSD test, $P<0.05$ )

afford tetrahydroisoquinolinone $(2.4 \mathrm{mg})$, thalifoline $(0.2 \mathrm{mg})$, and 6,7-dimethoxyisoquinoline $(1.2 \mathrm{mg})$. Fractions AC-5, -6, and -7 were combined and separated by $\mathrm{SiO}_{2} \mathrm{CC}$ eluted with a solvent mixture of chloroform/methanol (19:1). Recrystallization of the resulting subfractions afforded homovanillyl alcohol (3.5 mg).

The polar fractions B-1 and -2 were combined and applied to a reverse-phase Sephadex LH-20 column eluted with a step gradient of water and methanol $(10: 0,7: 3,5: 5,3: 7,0: 10)$ to result in several subfractions. Further resolved by repeated Sephadex LH-20 CC and recrystallization of the minor fractions produced $(+)$-catechin $(4.0 \mathrm{mg}),(-)$-epicatechin $(1.3 \mathrm{mg})$, and $(+)$-epicatechin $(0.7 \mathrm{mg})$. Fraction $\mathrm{B}-3$ was separated by $\mathrm{SiO}_{2} \mathrm{CC}$ eluted with a solvent mixture of chloroform/methanol $(5: 1$ to $1: 1$ ) and yielded five subfractions. Subfraction B-3-2 was further resolved by $\mathrm{SiO}_{2} \mathrm{CC}$ eluted with chloroform/methanol $(5: 1)$ solvent mixture and recrystallization of the minor fractions yielded (-)-epicatechin (6.4 mg), scopolin ( $2.1 \mathrm{mg})$, and 5,6-dimethoxybenzene-1,3-diol (2.4 mg). Subfractions B-3-3 and B-3-4 were purified by pTLC eluted with chloroform/methanol $(5: 1)$ to afford vanillic acid (3.6 mg), syringic acid (5.5 mg); and grasshopper ketone (5.7 mg), respectively. B-3-4 was further isolated by $\mathrm{SiO}_{2} \mathrm{CC}$ eluted with chloroform/methanol $(5: 1)$ and pTLC separation of the resulting minor fractions yielded machilusoxide A (6) (2.3 mg). Fractions B-4, B-5, and B-6 was respectively separated by $\mathrm{SiO}_{2}$ CC eluted with a solvent mixture of chloroform/methanol $(9: 1$ to $1: 1)$ and further $\mathrm{CC}$ and recrystallization of the subfractions produced totally lyoniside (8.6 mg), 2,4,6-trimethoxyphenol (17.2 mg), lyoniresol (9.2 mg), 3,4,5-trimethoxyphenyl- $\beta$-D-glucopyranoside ( $7.2 \mathrm{mg}$ ).

The water soluble fractions $\mathrm{W}-1$ and -2 were combined and applied to a reverse-phase Sephadex LH-20 column eluted with a step gradient of water and methanol $(10: 0,7: 3,5: 5,3: 7$, $0: 10)$ to result in several subfractions. Recrystallization of the subfractions yielded vanillic acid $(0.8 \mathrm{mg})$ and syringic acid $(1.2$ $\mathrm{mg}$ ). Fractions W-3 and -4 were purified by $\mathrm{SiO}_{2} \mathrm{CC}$ eluted with a solvent mixture of chloroform/methanol ( $6: 1$ to $1: 1)$, and further CC and recrystallization of the minor fractions produced (-)-epicatechin $(2.3 \mathrm{mg})$ and lyoniresol $(1.8 \mathrm{mg})$. Fractions W-5 and -6 were subjected to $\mathrm{SiO}_{2}$ CC eluted with a solvent mixture of chloroform/methanol $(9: 1$ to $1: 1)$, and further recrystallization of the subfractions of W-5 generated grasshopper ketone $(2.2 \mathrm{mg}$ ). Subfraction $\mathrm{W}-6-2$ was isolated by $\mathrm{SiO}_{2} \mathrm{CC}$ eluted with a solvent mixture of chloroform/methanol $(9: 1$ to $1: 1)$ and further pTLC purification of the minor fractions eluted with chloroform/methanol $(5: 1)$ afforded scopoletin $(0.5 \mathrm{mg})$, lyoniresol $(1.2 \mathrm{mg})$, and isofraxidin $(1.1 \mathrm{mg})$.

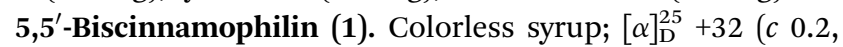
$\left.\mathrm{CHCl}_{3}\right) ; \mathrm{UV}(\mathrm{MeOH}) \lambda_{\max }(\log \varepsilon) 280$ (2.9), 227 (3.5) nm; CD $\left(\mathrm{MeOH}, c 8.33 \times 10^{-4} \mathrm{M}\right)(\mathrm{mol}$. CD) 277 (+20.3), $235(-8.9), 217$ $(+15.7) \mathrm{nm}$; IR (KBr) $\nu_{\max } 3393,2960,2931,1708,1665$, $1592 \mathrm{~cm}^{-1} ;{ }^{1} \mathrm{H}$ and ${ }^{13} \mathrm{C}$ NMR, see Tables 1 and 2; ESIMS (rel. int.) $m / z 709\left([\mathrm{M}+\mathrm{Na}]^{+}, 100\right)$; HRESIMS $m / z 709.2992\left([\mathrm{M}+\mathrm{Na}]^{+}\right.$calcd for $\mathrm{C}_{40} \mathrm{H}_{46} \mathrm{O}_{10} \mathrm{Na}, 709.2989$ ).

Machilupin A (2). Colorless syrup; $[\alpha]_{\mathrm{D}}^{25}+28(c 0.03, \mathrm{MeOH})$; $\mathrm{UV}(\mathrm{MeOH}) \lambda_{\max }(\log \varepsilon) 316$ (3.2), 285 (3.2), 235 (3.5) nm; IR (KBr) $\nu_{\max } 3402,2924,2858,1703,1643,1588,1546 \mathrm{~cm}^{-1} ;{ }^{1} \mathrm{H}$ and ${ }^{13} \mathrm{C}$ NMR, see Tables 1 and 2; EIMS (rel. int.) $m / z 358$ ([M] $\left.]^{+}, 17\right), 315$ (36), 286 (100); HREIMS $m / z 358.1414$ ([M] $]^{+}$, calcd for $\mathrm{C}_{20} \mathrm{H}_{22} \mathrm{O}_{6}$, 358.1416).

Machilupin B (3). Colorless syrup; $[\alpha]_{\mathrm{D}}^{25}+68(c 0.02, \mathrm{MeOH})$; $\mathrm{UV}(\mathrm{MeOH}) \lambda_{\max }(\log \varepsilon) 317$ (2.8), 282 (3.2), 237 (3.5) nm; IR (KBr) $\nu_{\max } 3610,1711,1682,1514,1488 \mathrm{~cm}^{-1} ;{ }^{1} \mathrm{H}$ and ${ }^{13} \mathrm{C}$ NMR, see Tables 1 and 2; EIMS (rel. int.) $m / z 358$ ([M] $\left.]^{+}, 34\right), 340$ (20), 287 (100), 177 (12), 43 (21); HREIMS $m / z 358.1416\left([\mathrm{M}]^{+}\right.$, calcd for $\left.\mathrm{C}_{20} \mathrm{H}_{22} \mathrm{O}_{6}, 358.1416\right)$.

Machilupin C (4). Colorless powder, mp 132-134 ${ }^{\circ} \mathrm{C}$; $[\alpha]_{\mathrm{D}}^{25}+26(c 0.04, \mathrm{MeOH}) ; \mathrm{UV}(\mathrm{MeOH}) \lambda_{\max }(\log \varepsilon) 281(2.6) \mathrm{nm}$; $\mathrm{CD}\left(\mathrm{MeOH}, c 5.00 \times 10^{-4} \mathrm{M}\right)(\mathrm{mol} . \mathrm{CD}) 276(+20.5), 235(-10.5)$, $217(+22.0) \mathrm{nm}$; IR (KBr) $\nu_{\max } 3447,2961,2928,1607,1513 \mathrm{~cm}^{-1}$; ${ }^{1} \mathrm{H}$ and ${ }^{13} \mathrm{C}$ NMR, see Tables 1 and 2; EIMS (rel. int.) $\mathrm{m} / \mathrm{z} 346$ ([M] $\left.]^{+}, 5\right), 259$ (100); HREIMS $\mathrm{m} / \mathrm{z} 346.1783$ ([M] $]^{+}$, calcd for $\left.\mathrm{C}_{20} \mathrm{H}_{26} \mathrm{O}_{5}, 346.1780\right)$.

Machilutone A (5). Colorless syrup; $[\alpha]_{\mathrm{D}}^{25}+23(c 0.08, \mathrm{MeOH})$; $\mathrm{UV}(\mathrm{MeOH}) \lambda_{\max }(\log \varepsilon) 281$ (3.8), $259(3.6) \mathrm{nm}$; IR (KBr) $\nu_{\max }$ $3396,1660,1598,1511 \mathrm{~cm}^{-1} ;{ }^{1} \mathrm{H}$ and ${ }^{13} \mathrm{C}$ NMR, see Tables 1 and 2; EIMS (rel. int.) $m / z 340$ ([M] $\left.]^{+}, 100\right), 325$ (32), 309 (27), 293 (19), 120 (26); HRESIMS $\mathrm{m} / \mathrm{z} 363.1206\left([\mathrm{M}+\mathrm{Na}]^{+}\right.$, calcd for $\mathrm{C}_{20} \mathrm{H}_{20} \mathrm{O}_{5} \mathrm{Na}$, 363.1208).

Machilusoxide A (6). Colorless syrup; $[\alpha]_{\mathrm{D}}^{25}+28\left(\begin{array}{cc}c & 0.05 \\ \text {, }\end{array}\right.$ $\mathrm{MeOH}$ ); UV (MeOH) $\lambda_{\max }(\log \varepsilon) 273$ (2.9), 249 (2.8) nm; IR (KBr) $\nu_{\max } 3509,3003,2938,1713,1422,1362,1224 \mathrm{~cm}^{-1} ;{ }^{1} \mathrm{H}-\mathrm{NMR}$ $\left(\mathrm{CD}_{3} \mathrm{OD}, 300 \mathrm{MHz}\right) \delta 7.70(1 \mathrm{H}, \mathrm{d}, J=16.2 \mathrm{~Hz}, \mathrm{H}-4), 6.23(1 \mathrm{H}$, $\mathrm{d}, J=16.2 \mathrm{~Hz}, \mathrm{H}-5), 5.85(1 \mathrm{H}, \mathrm{s}, \mathrm{H}-2), 4.09(1 \mathrm{H}, \mathrm{tdd}, J=10.8,6.6$, $\left.3.3 \mathrm{~Hz}, \mathrm{H}-4^{\prime}\right), 3.79\left(1 \mathrm{H}, \mathrm{d}, J=6.4 \mathrm{~Hz}, \mathrm{H}-8^{\prime}\right), 3.68(1 \mathrm{H}, \mathrm{d}, J=$ $\left.6.4 \mathrm{~Hz}, \mathrm{H}-8^{\prime}\right), 2.04\left(1 \mathrm{H}, \mathrm{m}, \mathrm{H}-3^{\prime}\right), 1.98\left(3 \mathrm{H}, \mathrm{s}, \mathrm{CH}_{3}-6\right), 1.83(1 \mathrm{H}, \mathrm{m}$, $\left.\mathrm{H}-5^{\prime}\right), 1.15\left(3 \mathrm{H}, \mathrm{s}, \mathrm{CH}_{3}-9^{\prime}\right), 0.92\left(3 \mathrm{H}, \mathrm{s}, \mathrm{CH}_{3}-7^{\prime}\right) ;{ }^{13} \mathrm{C}-\mathrm{NMR}$ $\left(\mathrm{CD}_{3} \mathrm{OD}, 75 \mathrm{MHz}\right) \delta 175.0$ (C-1), 139.7 (C-3), 132.6 (C-4), 129.5 (C-5), 128.1 (C-2), 87.2 (C-2'), 82.7 (C-1'), $76.8\left(\mathrm{C}-8^{\prime}\right), 65.6\left(\mathrm{C}-6^{\prime}\right)$, 
$63.7\left(\mathrm{C}-4^{\prime}\right), 45.4\left(\mathrm{C}-3^{\prime}\right), 44.0\left(\mathrm{C}-5^{\prime}\right), 19.9(\mathrm{C}-6), 19.1\left(\mathrm{C}^{\prime} 7^{\prime}\right), 15.8$ (C$\left.9^{\prime}\right)$; HRESIMS $m / z 281.1382\left([\mathrm{M}-\mathrm{Na}]^{-}\right.$calcd for $\mathrm{C}_{15} \mathrm{H}_{21} \mathrm{O}_{5}$, 281.1389).

\section{Primary cortical neuronal culture}

Cultured cortical cells were collected from the cerebral cortices of Sprague-Dawley rats (1 day-old) under pentobarbital anesthesia according to the previous report. ${ }^{55}$ The cortices were kept in ice-cold Dulbecco's modified Eagle's medium (DMEM; GIBCO) and minced. Tissue chunks were then incubated in a papain solution ( $0.6 \mathrm{mg} \mathrm{mL}^{-1}$ papain and DNase I in HBSS) at $37{ }^{\circ} \mathrm{C}$ for $30 \mathrm{~min}$ to dissociate the cells, and the reaction was stopped by addition of heat-inactivated horse serum. After the cell suspensions were centrifuged at $800 \mathrm{~g}$, pellets were plated onto poly-D-lysine-coated Petri dishes. Dissociated cells were suspended in DMEM with $10 \%$ horse serum and incubated at $37{ }^{\circ} \mathrm{C}$ in a humidified incubator with $5 \% \mathrm{CO}_{2}$. Three hours after plating, the culture medium was replaced by a serum-free neurobasal medium containing $25 \mu \mathrm{M}$ glutamate, $0.5 \mathrm{mM} \mathrm{L}^{-}$ glutamine, and $2 \% \mathrm{~B}_{27}$ supplement (17504-044; Invitrogen Corp., Carlsbad, CA, USA). Cultured cells were allowed to grow for approximately 7-14 days. These cultures contained 80\% neurons and $20 \%$ astrocytes, as determined by immunohistochemistry using monoclonal antibodies against microtubuleassociated protein-2 (MAP-2; Boehringer Mannheim, Mannheim, Germany) and glial fibrillary acidic protein (GFAP, Sigma-Aldrich).

\section{Glutamate-induced oxidative stress assay}

For cytotoxicity studies, cells were plated onto poly-D-lysinecoated 24 well dishes at a density of $2 \times 10^{6}$ cells per well. All studies were initiated within 7-14 day after plating. Cinnamophilin (7) was dissolved in dimethylsulfoxide (DMSO) (final concentration $<0.1 \%)$ or MK-801 $(20 \mu \mathrm{M})$ which is a glutamate receptor inhibitor ${ }^{56}$ was co-applied with $\mathrm{L}$-glutamate to the cultures. Neuronal cultures were exposed to $300 \mu \mathrm{M}$ glutamate (Sigma) in the absence or presence of compounds in a $\mathrm{CO}_{2}$ buffered incubator at $37{ }^{\circ} \mathrm{C}$ for 24 hours. Cell damage was assessed by fluorescent image analysis of propidium iodide (PI) uptake and by differential interference contrast (DIC) image analysis of trypan blue uptake (Sigma). After co-applied incubation for 24 hours, cells were washed with Earle's balanced salt solution three times, $1 \% 10 \mu \mathrm{g} \mathrm{mL}^{-1}$ PI and $4 \%$ trypan blue was added to the cultures and incubated for $20 \mathrm{~min}$ and $5 \mathrm{~min}$. Trypan blue in cell released out by treating $1 \%$ Triton X-100 and measured the absorbance at $600 \mathrm{~nm}$.

\section{Lactate dehydrogenase (LDH) release assay}

Cell death was quantified by LDH levels in the extracellular medium and measured by using a LDH assay kit (Promega, Madison, WI, USA). Following the procedures provided by the vendor, the values of $\mathrm{LDH}$ were measured by the optical density (OD) taken at $490 \mathrm{~nm}$ in a plate reader (Stat Fax 2100; Awareness Technology, Inc.). Data are expressed as a value of the response $\%$, i.e. a percentage relative to the values obtained from the medium of the glutamate-treated control neuronal cultures.

\section{Statistical analysis}

The data were expressed as the mean \pm standard error of the mean (S.E.M.). Paired Students' $t$ test was used to evaluate the response to a change in conditions, and one-way analysis of variance (one-way ANOVA) with Fisher's protected least significant difference post hoc comparison was used to evaluate differences between groups. $P<0.05$ was selected for statistical significance.

\section{Conclusions}

In summary, one dimeric lignin biscinnamophilin (1), four lignans machilupins A-C (2-4) and machilutone A (5), along with one ionone machilusoxide A (6) are characterized with spectroscopic and spectrometric analysis. Although there were a few papers reported the chemical constituents from this species, ${ }^{57}$ the present report was the first study about its comprehensive chemical composition. The most abundant compound, cinnamophilin (7), was examined for its bioactivity in the primary cortical neurons culture by glutamate-induced oxidative stress assay for the first time. The experimental data evidenced the stem extracts of $M$. philippinensis and related principles as the potential neuroprotective drug candidates.

\section{Conflicts of interest}

There are no conflicts to declare.

\section{Acknowledgements}

This study is sponsored by the Ministry of Science and Technology (MOST), Taiwan.

\section{Notes and references}

1 B. M. Demaerschalk and T. R. Yip, Stroke, 2005, 36, 25002503.

2 D. J. Gladstone, S. E. Black and A. M. Hakim, Stroke, 2002, 33, 2123-2136.

3 B. Schaller, Free Radical Biol. Med., 2005, 38, 411-425.

4 S. M. Yu, F. N. Ko, T. S. Wu, J. Y. Lee and C. M. Teng, Eur. J. Pharmacol., 1994, 256, 85-91.

5 S. M. Yu, T. S. Wu and C. M. Teng, Br. J. Pharmacol., 1994, 111, 906-912.

6 G. Hsiao, C. M. Teng, J. R. Sheu, Y. W. Cheng, K. K. Lam, Y. M. Lee, T. S. Wu and M. H. Yen, Biochim. Biophys. Acta, 2001, 1525, 77-88.

7 E. J. Lee, H. Y. Chen, M. Y. Lee, T. Y. Chen, Y. S. Hsu, Y. L. Hu, G. L. Chang and T. S. Wu, Free Radical Biol. Med., 2005, 39, 495-510.

8 E. J. Lee, H. Y. Chen, Y. C. Hung, T. Y. Chen, M. Y. Lee, S. C. Yu, Y. H. Chen, I. C. Chuang and T. S. Wu, Exp. Neurol., 2009, 217, 74-83.

9 T. Y. Chen, S. H. Tai, E. J. Lee, C. C. Huang, A. C. Lee, S. Y. Huang and T. S. Wu, Crit. Care Med., 2011, 39, 11301137. 
10 I. L. Tsai, J. H. Chen, C. Y. Duh and I. S. Chen, Planta Med., 2000, 66, 403-407.

11 I. L. Tsai, J. H. Chen, C. Y. Duh and I. S. Chen, Planta Med., 2001, 67, 559-561.

12 M. J. Cheng, B. Jayaprakasam, T. Ishikawa, H. Seki, I. L. Tsai, J. J. Wang and I. S. Chen, Helv. Chim. Acta, 2002, 85, 19091914.

13 G. Li, C. S. Lee, M. H. Woo, S. H. Lee, H. W. Chang and J. K. Son, Biol. Pharm. Bull., 2004, 27, 1147-1150.

14 Y. U. Yu, S. Y. Kang, H. Y. Park, S. H. Sung, E. J. Lee, S. Y. Kim and Y. C. Kim, J. Pharm. Pharmacol., 2000, 52, 1163-1169.

15 W. C. Hou, R. D. Lin, K. T. Cheng, Y. T. Hung, C. H. Cho, C. H. Chen, S. Y. Hwang and M. H. Lee, Phytomedicine, 2003, 10, 170-175.

16 N. Y. Kim and J. H. Ryu, Phytother. Res., 2003, 17, 372-375.

17 T. S. Wu, Y. L. Leu, Y. Y. Chan, S. M. Yu, C. M. Teng and J. D. Su, Phytochemistry, 1994, 36, 785-788.

18 T. S. Wu, C. M. Teng and S. M. Yu, US Pat. 5656274 A12, 1997.

19 C. J. Ma, S. H. Sung and Y. C. Kim, Planta Med., 2004, 70, 7980.

20 C. J. Ma, S. R. Kim, J. Kim and Y. C. Kim, Br. J. Pharmacol., 2005, 146, 752-759.

21 K. Reyes-Melo, A. García, A. Romo-Mancillas, E. GarzaGonzález, V. M. Rivas-Galindo, L. D. Miranda, J. VargasVillarreal, J. M. J. Favela-Hernández and M. D. R. Camacho-Corona, Bioorg. Med. Chem., 2017, 25, 5247-5259.

22 J. M. J. Favela-Hernández, A. García, E. Garza-González, V. M. Rivas-Galindo and M. D. R. Camacho-Corona, Phytother. Res., 2012, 26, 1957-1960.

23 M. M. M. Pinto, A. Kujoa, I. O. Mondranondra and A. B. G. Werner, Phytochemistry, 1988, 29, 1985-1990.

24 N. Nakatani, K. Ikeda, H. Kikuzaki, M. Kido and Y. Yamaguchi, Phytochemistry, 1988, 27, 3127-3129.

25 H. Shibuya, Y. Takeda, R. S. Zhang, A. Tanitame, Y. L. Tsai and I. Kitagawa, Chem. Pharm. Bull., 1992, 40, 2639-2646.

26 S. Inoshiri, M. Sasaki, H. Otsuka and K. Yamasaki, Phytochemistry, 1987, 26, 2811-2814.

27 H. Karikome, Y. Mimaki and Y. Sashida, Phytochemistry, 1991, 30, 315-319.

28 R. W. Hemingway, F. L. Tobiason, G. W. McGraw and J. P. Steynberg, Magn. Reson. Chem., 1996, 34, 424-433.

29 T. Masuda, S. Mizuguguchi, T. Tanaka, K. Iritani and Y. Takeda, J. Agric. Food Chem., 2000, 48, 1479-1484.

30 H. Ishii, T. Ishikawa, H. Wada, H. Miyazaki, Y. Kaneko and T. Harayama, Chem. Pharm. Bull., 1992, 40, 2614-2619.

31 D. V. Banthorpe and G. D. Brown, Phytochemistry, 1989, 28, 3003-3007.

32 W. W. Li and W. Barz, Planta Med., 2006, 72, 248-254.

33 P. A. Spencer, A. Tanaka and G. H. N. Towers, Phytochemistry, 1990, 29, 3785-3788.

34 J. Tan, P. Bednarek, J. Liu, B. Schneider, A. Svatos and K. Hahlbrock, Phytochemistry, 2004, 65, 691-699.
35 H. Shimomura, Y. Sashida, M. Oohara and H. Tenma, Phytochemistry, 1988, 27, 644-646.

36 Y. Li, M. R. Meselhy, L. Q. Wang, C. M. Ma, N. Nakamura and M. Hattroi, Chem. Pharm. Bull., 2000, 48, 1239-1241.

37 Y. Hashidoko, S. Tahara and J. Mizutani, Phytochemistry, 1992, 31, 3282-3283.

38 Y. R. Govindachari, P. C. Parthasrathy, H. K. Desai and P. A. Mohamed, Indian J. Chem., 1971, 63, 1027.

39 M. Selva and P. Tundo, J. Org. Chem., 2006, 71, 1464-1470.

40 S. Christophoridu, P. Dais, L. H. Tseng and M. Spraul, J. Agric. Food Chem., 2005, 53, 4667-4679.

41 M. Lucarini, P. Pedrielli, G. F. Pedulli, S. Cabiddu and C. Fattuoni, J. Org. Chem., 1996, 61, 9259-9263.

42 F. R. Chang, C. Y. Chen, T. J. Hsieh, C. P. Cho and Y. C. Wu, J. Chin. Chem. Soc., 2000, 47, 913-920.

43 B. N. Su, E. J. Park, D. Nikolic, J. S. Vigo, J. G. Graham, F. Cabieses, R. B. Breemen, H. H. S. Fong, N. R. Farnsworth, J. M. Pezzuto and A. D. Kinghorn, J. Nat. Prod., 2003, 66, 1089-1093.

44 B. C. Michele, M. D. Paolis and J. Zhu, Tetrahedron Lett., 2001, 42, 3427-3430.

45 S. Hibino, E. Sugino, Y. Adachi, K. Nomi and K. Sato, Heterocycles, 1989, 28, 275-282.

46 C. T. Chen, F. R. Chang, C. M. Teng and Y. C. Wu, J. Chin. Chem. Soc., 1999, 46, 77-86.

47 B. Y. Hwang, B. N. Su, H. Chai, Q. Mi, L. B. S. Kardono, J. J. Afriastini, S. Riswan, B. D. Santarsiero, A. D. Mesecar, R. Wild, C. R. Fairchild, G. D. Vite, W. C. Rose, N. R. Farnsworth, G. A. Cordell, J. M. Pezzuto, S. M. Swanson and A. D. Kinghorn, J. Org. Chem., 2004, 69, 3350-3358.

48 V. Singh, A. Khurana, I. Kaur, V. Sapehiyla, G. L. Kad and J. Singh, J. Chem. Soc., Perkin Trans. 1, 2002, 1766-1768.

49 B. Talapatra, S. Goswami, A. Ghash and S. K. Talapetra, J. Indian Chem. Soc., 1982, 59, 1364-1368.

50 V. J. C. Martinez, S. L. E. Cuca, M. A. J. Santana, E. PomboVillar and B. I. Golding, Phytochemistry, 1985, 24, 1612-1614.

51 D. Wang, Y. Mu, H. Dong, H. Yan, C. Hao, X. Wang and L. Zhang, Molecules, 2018, 23, 72.

52 W. J. Davies and H. G. Jones, in Abscisic acid: Physiology and Biochemistry, BIOS Scientific Publishers, Oxford, 1991.

53 C. Y. Chen, Y. T. Yeh and Y. R. Hsui, Chem. Nat. Compd., 2011, 47, 519-520.

54 J. C. T. Reddel, W. Wang, K. Koukounas and R. J. Thomson, Chem. Sci., 2017, 8, 2156-2160.

55 S. H. Tai, Y. C. Hung, E. J. Lee, A. C. Lee, T. Y. Chen, C. C. Shen, H. Y. Chen, M. Y. Lee, S. Y. Huang and T. S. Wu, J. Pineal Res., 2011, 50, 292-303.

56 R. L. Kraus, R. Pasieczny, K. Lariosa-Willingham, M. S. Turner, A. Jiang and J. W. Trauger, J. Neurochem., 2005, 94, 819-827.

57 Y. R. Hsui, H. L. Chen, C. T. Chen and C. Y. Chen, Chem. Nat. Compd., 2013, 49, 79-80. 